\title{
IMPLEMENTASI KURIKULUM 2013 DI MADRASAH IBTIDAIYAH KAHASRI KOTA PROBOLINGGO
}

\author{
Allifatur Rohma \\ alif.fatur286@gmail.com
}

\begin{abstract}
ABSTRAK
Madrasah Ibtidaiyah of KAHASRI is an institution appointed by the Indonesian Ministry of Religion to implement the 2013 Curriculum or called Kl3 both in thematic and religious learning which is in line with Decree of the Director of Islamic Education Number 3525 in 2017 about Determination of the Implementation of the 2013 Curriculum. This research focused on the implementation of 2013 curriculum management. This research used a qualitative approach and the type was case study. Determination of research subjects was purposively. Data collection techniques were interviews, observation, and documentation. Interactive data analysis used Miles and Huberman model, with the following steps; condensation, data presentation, and verification. The results of this research reveals that; 1 ) learning design of $\mathrm{kl3}$ is the teacher in Madrasah Ibtidaiyah KAHASRI of Probolinggo make learning tools such as Educational Calendar, RPE, Prota, Promissory Notes, Syllabus, and RPP. In making learning tools, there is a teacher who makes individually and together KKG (Teacher Working Group). 2) the implementation of K13 learning in Madrasah Ibtidaiyah KAHASRI of Probolinggo has three activities such as; introduction, essence, and closing. In introduction preceded by giving apperception, giving motivation, delivering purpose and the benefit of learning. In the essence activity the teacher had done scientific activity such as; observe, ask questions, try, associate / collect, and communicate. In closing, the teacher made a conclusion of material given and gave task. (3) Evaluation of Kl3 learning in Madrasah Ibtidaiyah KAHASRI of Probolinggo used authentic assessment models including three aspect; aspects of attitude, aspects of knowledge, and aspects of skills.
\end{abstract}

Kata Kunci : Implementasi, Kurikulum 2013 


\section{PENDAHULUAN}

Madrasah Ibtidaiyah KAHASRI merupakan salah satu Madrasah Ibtidaiyah di Kota Probolinggo yang pertama kali menerapkan kurikulum 2013. Madrasah Ibtidaiyah KAHASRI ini telah menerapkan kurikulum 2013 sejak tahun pelajaran 2017/2018. Pada awal diimplementasikannya Kurikulum 2013 telah menuai banyak kontroversi. Penyiapan Kurikulum 2013 dinilai terlalu terburu-buru dan tidak mengacu pada hasil kajian yang sudah matang berdasarkan hasil KTSP dan kurang memperhatikan kesiapan satuan pendidikan dan guru. Hal ini juga dirasakan oleh guru di Madrasah Ibtidaiyah KAHASRI Kota Probolinggo

Dengan demikian, guru merupakan salah satu faktor penting dalam implementasi kurikulum 2013. Idealnya suatu kurikulum tanpa ditunjang oleh kemampuan guru maka kurikulum akan tidak bermakna, sebaliknya pembelajaran tanpa kurikulum sebagai pedoman tidak akan efektif. Kurikulum 2013 akan sulit dilaksanakan di berbagai daerah apabila guru belum siap. Ketidaksiapan guru tidak hanya urusan kompetensinya, tetapi masalah kreativitasnya. Tugas guru tidak hanya menyampaikan informasi kepada peserta didik, tetapi harus kreatif memberikan layanan dan kemudahan belajar kepada peserta didik agar dapat belajar dalam suasana yang menyenangkan, penuh semangat, dan berani mengemukakan pendapat.

Guru sebagai pelaksana kurikulum selalu melakukan evaluasi dalam pembelajaran. Untuk mendukung keefektifan dalam pelaksanaan kurikulum 2013, maka guru harus memahami struktur dan substansi kurikulum 2013 serta menguasai perencanaan, pelaksanaan dan evaluasi pembelajaran kurikulum 2013. Implementasi kurikulum 2013 di Madrasah Ibtidaiyah KAHASRI Kota Probolinggo diharapkan mampu memberikan kesempatan kepada peserta didik untuk belajar sesuai dengan kebutuhannya dan guru berfungsi sebagai fasilitator dalam pembelajaran.

Dalam Kurikulum 2013, proses pembelajaran merupakan salah satu elemen dari standar proses yang mengalami perubahan guna pencapaian keberhasilan pembelajaran dan pembentukan kompetensi peserta didik. Pemerintah dalam Peraturan Menteri Pendidikan dan Kebudayaan Republik Indonesia No. 65 Tahun 2013 tentang standar proses pendidikan dasar dan menengah menjelaskan bahwa dalam mengimplementasikan proses pembe- 
lajaran di kurikulum 2013 pada satuan pendidikan harus diselenggarakan secara interaktif, inspiratif, menyenangkan, menantang, memotivasi peserta didik untuk berpartisipasi aktif, serta memberikan ruang yang cukup bagi prakarsa, kreativitas, dan kemandirian sesuai dengan bakat, minat, dan perkembangan fisik serta psikologis peserta didik. ${ }^{1}$

Kurikulum 2013 dirancang untuk menghadirkan pembelajaran yang ideal, sehingga menghasilkan output yang ideal pula. Pembelajaran dalam kurikulum 2013 menganut beberapa hal yaitu: (1) pembelajaran yang dilakukan guru (taught curriculum) dalam bentuk proses yang dikembangkan berupa kegiatan pembelajaran di madrasah, kelas, dan masyarakat; dan (2) pengalaman belajar langsung peserta didik (learned-curriculum) sesuai dengan latar belakang, karakteristik, dan kemampuan awal peserta didik. ${ }^{2}$

Dalam suatu kegiatan pembelajaran terdiri dari beberapa komponen. Komponen-komponen yang terdiri dari suatu pembelajaran diantaranya perencanaan pembelajaran, pelaksanaan pembelajaran, dan evaluasi pembelajaran.

\section{Perencanaan Pembelajaran Kurikulum 2013}

Perencanaan pembelajaran adalah proses pengambilan keputusan hasil berpikir secara rasional tentang sasaran dan tujuan pembelajaran tertentu, yakni perubahan perilaku serta rangkaian kegiatan yang harus dilaksanakan sebagai upaya pencapaian tujuan tersebut dengan memanfaatkan segala potensi dan sumber belajar yang ada. ${ }^{3}$ Dengan demikian, perencanaan pembelajaran dilakukan untuk menyusun kegiatan pembelajaran sebagai upaya pencapaian tujuan implementasi sistem kurikulum.

Berdasarkan Permendikbud Nomor 22 tahun 2016 tentang Standar Proses, perencanaan pembelajaran dirancang dalam bentuk Silabus dan Rencana Pelaksanaan Pembelajaran (RPP) yang mengacu pada Standar isi. Perencanaan pembelajaran meliputi penyusunan rencana pelaksanaan pem-

\footnotetext{
${ }^{1}$ Peraturan Menteri Pendidikan dan Kebudayaan Republik Indonesia No. 65 Tahun 2013 tentang standar proses pendidikan dasar dan menengah

${ }^{2}$ Peraturan Menteri Pendidikan dan Kebudayaan Republik Indonesia Nomor 68 Tahun 2013 tentang Kurikulum SMP-MTs

3 Wina Sanjaya, Perencanaan Pembelajaran dan Diseain Sistem Pembelajaran, (Jakarta: Kencana Prenada Media Group, 2009), 28
} 
belajaran dan penyiapan media dan sumber belajar, perangkat penilaian pembelajaran, dan skenario pembelajaran. ${ }^{4}$

Pada tahap perencanaan, guru diwajibkan menyusun Rencana Pelaksanaan Pembelajaran (RPP), dimana guru menelaah Kompetensi Dasar (KD) yang diharapkan dikuasai oleh peserta didik, lalu merumuskan Indikator Ketercapaian Kompetensi (IKK) dengan menggunakan Kata Kerja Operasional (KKO) yang dapat diukur, utamanya pada aspek kognitif dan psikomotor.

Dari kata-kata kunci pada aspek kognitif, afektif, dan psikomotor, dikembangkan lagi ke dalam ratusan KKO yang disesuaikan dengan IKK yang dicapai pada tiap KD. Sesuai dengan harapan Kemendikbud bahwa perserta didik dibelajarkan dalam situasi HOTS (Higher Order Thinking Skills).

\section{Pelaksanaan Pembelajaran Kurikulum 2013}

Menurut Permendikbud 81A Tahun 2013 dijelaskan bahwa kegiatan pembelajaran merupakan proses pendidikan yang memberikan kesempatan kepada peserta didik untuk mengembangkan potensi mereka menjadi kemampuan yang semakin lama semakin meningkat dalam sikap, pengetahuan, dan keterampilan yang diperlukan dirinya untuk hidup dan untuk bermasyarakat, berbangsa, serta berkontribusi pada kesejateraan hidup umat manusia. Oleh karena itu, kegiatan pembelajaran diarahkan untuk memberdayakan semua potensi peserta didik menjadi kompetensi yang diharapkan. ${ }^{5}$

Pelaksanaan pembelajaran kurikulum 2013 pada dasarnya merupakan perwujudan dari RPP yang memuat seluruh kegiatan pembelajaran. Pelaksanaan pembelajaran memuat interaksi guru dan peserta didik dengan lingkungan sekitar sehingga diharapkan peserta didik dapat memanfaatkan pengalaman yang diperoleh dari guru dan lingkungan sekitar.

Dalam pelaksanaan pembelajaran, tentu tidak bisa terlepas dari Rencana Pelaksanaan Pembelajaran (RPP) yang telah dibuat. Sebab, RPP merupakan gambaran atau perencanaan singkat tentang pembelajaran yang akan

\footnotetext{
${ }^{4}$ Peraturan Menteri Pendidikan dan Kebudayaan Republik Indonesia Nomor 22 Tahun 2016 tentang Standar Proses Pendidikan Dasar dan Menengah

${ }^{5}$ F Fadlilah, Implementasi Kurikulum 2013, (Yogyakarta: Ar-Ruzz Media, 2017), 179
} 
dilakakan. Dengan kata lain, RPP adalah acuan utama dalam melaksanakan pembelajaran. Oleh karenanya, seorang guru wajib mempersiapkan RPP terlebih dahulu sebelum melaksanakan pembelajaran. ${ }^{6}$

Pelaksanaan pembelajaran kurikulum 2013 terbagi atas tiga kegiatan pokok meliputi kegiatan pendahuluan, kegiatan inti dan akhir. Ketiga kegiatan terebut tersusun menjadi satu dalam suatu kegiatan pembelajaran dan tidak dapat dipisah-pisahkan satu dengan yang lain. Untuk lebih jelasnya berikut pelaksanaan pembelajaran yang dimaksud.

a. Kegiatan Pendahuluan

Kegiatan pendahuluan merupakan kegiatan pembukaan pembelajaran. Biasanya alokasi waktu untuk kegiatan pendahuluan ialah 15 menit.

b. Kegiatan Inti

Kegiatan inti adalah kegiatan yang paling penting dan utama dalam proses pembelajaran. Kegiatan inti merupakan proses pembelajaran untuk mencapai tujuan, yang dilakukan secara interaktif, inspiratif, menyenangkan, menantang, dan memotivasi peserta didik untuk secara aktif menjadi pencari informasi, serta memberikan ruang yang cukup bagi prakarsa, kreativitas, dan kemandirian sesuai dengan bakat, minat, dan perkembangan fisik serta psikologis peserta didik. Penerapan pendekatan saintifik diharapkan dapat mewujudkan pembelajaran berbasis HOTS. Langkah-langkah dalam mengimplementasikan pendekatan saitifik meliputi: mengamati, menanya, mengumpulkan dan mengasosiasi, serta mengkomunikasikan hasil.

c. Kegiatan Penutup

Kegiatan penutup atau kegiatan akhir adalah kegiatan yang dimaksudkan untuk mengakhiri proses pembelajaran. Waktu yang dapat digunakan untuk kegiatan penutupialah 10 menit akhir. Dalam kegiatan penutup, guru bersama peserta didik baik secara individual maupun kelompok melakukan refleksi untuk mengevaluasi

\section{Evaluasi Pembelajaran Kurikulum 2013}

Penilaian pembelajaran kurikulum 2013, penilaian yang digunakan ada-

\footnotetext{
${ }^{6}$ Ibid., 182
} 
lah penilaian autentik. Berdasarkan lampiran Permendikbud No. 66 Tahun 2013 tentang standar penilaian, penilaian autentik merupakan penilaian yang dilakukan secara komprehensif untuk menilai, mulai dari proses hingga keluaran (output) pembelajaran. Penilaian autentik mencakup ranah sikap, keterampilan, dan pengetahuan. ${ }^{7}$

Dalam penilaian autentik, guru didorong untuk membuat soal HOTS. Membuat HOTS tidak identik dengan soal yang panjang, sulit, dan berbelitbelit, tetapi soal yang meminimalkan aspek ingatan atau pengetahuan, bersifat kontekstual, memproses dan menerapkan informasi, mencari kaitan diantara informasi yang berbeda, menggunakan informasi untuk menyelesaikan masalah, dan menelaah informasi secara kritis.

\section{Metode Penelitian}

Pendekatan yang digunakan dalam penelitian ini adalah kualitatif dengan jenis penelitian studi kasus mendalam. Penelitian ini di lakukan di Madrasah Ibtidaiyah KAHASRI Kota Probolinggo yang berlokasi di Jl. Mayjen Hariyono No.91 Kelurahan Mangunharjo Kecamatan Mayangan Kota Probolinggo. Penentuan subyek penelitian secara purposive. Informan yang ditetapkan dalam penelitian ini adalah: Kepala Madrasah, Wakil Kepla Madrasah, Guru, dan Peserta Didik. Teknik pengumpulan data yaitu: wawancara, observasi, dan dokumentasi. Analisis data secara interaktif dengan model Miles dan Huberman, dengan langkah-langkah yaitu: kondensasi, penyajian data, dan verifikasi. Keabsahan data yang digunakan yaitu triangulasi sumber dan teknik.

\section{HASIL DAN PEMBAHASAN}

Perencanaan Pembelajaran Kurikulum 2013 di Madrasah Ibtidaiyah KAHASRI Kota Probolinggo Tahun Pelajaran 2018/2019

Berdasarkan hasil teman penelitian di Madrasah Ibtidaiyah KAHASRI Kota Probolinggo dalam perencanaan pembelajaran guru membuat perangkat pembelajaran berupa berupa Kalender Pendidikan, RPE, Prota, Promes,

${ }^{7}$ Sunarti, Selly Rahmawati, Penilaian dalam Kurikulum 2013: Membantu Guru dan Calon Guru Mengetahui Langkah-Langkah Penilaian Pembelajaran, (Yogyakarta: CV Andi Offset, 2014), 27 
Silabus, dan RPP. Dalam pembuatan perangkat pembelajaran ada guru yang membuat perangkat pembelajaran secara individu dan ada yang dengan bersama KKG (Kelompok Kerja Guru).

Temuan tersebut didialogkan dengan teori yang dikembangkan oleh Syahruddin Nurdin dan Andriantoni sebagai berikut:

Tahap perencanaan pembelajaran dalam penyelenggaraan proses pembelajaran terdapat sejumlah rangkaian kegiatan yang perlu direncanakan terlebih dahulu oleh guru diantaranya: kalender pendidikan, rencana pekan efektif, program tahunan, program semester, silabus, dan rencana pelaksanaan pembelajaran (RPP). ${ }^{8}$

Berdasarkan teori tersebut perencanaan pembelajaran guru perlu merencanakan perangkat pembelajaran meliputi: kalender pendidikan, rencana pekan efektif, program tahunan, program semester, silabus, dan rencana pelaksanaan pembelajaran (RPP).

Setelah temuan-temuan tersebut didiskusikan dengan teori yang dikembangkan oleh Syahruddin Nurdin dan Andriantoni, dapat dipahami bahwa guru Madrasah Ibtidaiyah KAHASRI Kota Probolinggo telah membuat perencanaan pembelajaran sesuai dengan teori. Meskipun dalam pelaksanaanya ada guru yang membuat sendiri dan ada juga guru yang membuat bersama-sama dengan KKG kemudian disesuaikan dengan kondisi peserta didik di sekolah.

\section{Pelaksanaan Pembelajaran Kurikulum 2013 di Madrasah Ibtidaiyah KAHASRI Kota Probolinggo Tahun Pelajaran 2018/2019}

Setelah guru menyusun perencanaan pembelajaran selanjutnya guru melaksanakan pembelajaran. Pada kegiatan pelaksanaan pembelajaran kegiatan yang dilakukan adalah proses belajar mengajar sebagai unsur inti dari aktivitas pembelajaran yang telah disusun dalam peencanaan pembelajaran sebelumnya.

Hasil penelitian yang digunakan dan data yang diperoleh di lapangan, pelaksanaan pembelajaran di Madrasah Ibtidaiyah KAHASRI Kota Probolinggo melaksanakan dengan tiga langkah, yaitu kegiatan pendahuluan, inti,

${ }^{8}$ Syafruddin Nurdin dan Adriantoni, Kurikulum dan Pembelajaran, (Jakarta: Rajawali Press Rosdajarya, 2016) 72 


\section{Allifatur Rohma}

dan penutup.

a. Kegiatan Pendahuluan

Pada kegiatan awal membuka pelajaran adalah untuk menarik perhatian peserta didik yang dapat dilakukan dengan cara seperti meyakinkan peserta didik bahwa materi atau pengalaman belajar yang akan dilakukan bergunan untuk dirinya. Menumbuhkan motivasi belajar peserta didik yang dapat dilakukan dengan cara membangun suasana akrab sehingga peserta didik merasa dekat. Dan memberikan acuan atau rambu-rambu tentang pembelajaran yang akan dilakukaan. ${ }^{9}$

Berdasarkan temuan hasil penelitian di Madrasah Ibtidaiyah KAHASRI Kota Probolinggo menunjukkan bahwa kegiatan pendahuluan diawali dengan memberikan apersepsi, memberikan stimulus/motivasi, dan menyampaikan tujuan dan manfaat pembelajaran. Selain itu, kegiatan pendahuluan diselingi dengan membaca doa sehari-hari dan surat-surat pendek. Kemudian peserta didik diajak untuk menyanyikan lagu nasional untuk meningkatkan rasa nasionalisme peseta didik. Kegiatan tersebut dapat merangsang peserta didik untuk mencapai Kompetensi Inti (KI) 1 dan 2 tentang sikap spiritual dan sosial.

Temuan tersebut sesuai dengan Permendikbud Nomor 103 tahun 2014 tentang Pedoman Pelaksanaan Pembelajaran yang memuat kegiatan yang harus dilakukan guru dalam pendahuluan, yaitu:

1) mengondisikan suasana belajar yang menyenangkan;

2) mendiskusikan kompetensi yang sudah dipelajari dan dikembangkan sebelumnya berkaitan dengan kompetensi yang akan dipelajari dan dikembangkan;

3) menyampaikan kompetensi yang akan dicapai dan manfaatnya dalam kehidupan sehari-hari;

4) menyampaikan garis besar cakupan materi dan kegiatan yang akan dilakukan; dan

5) menyampaikan lingkup dan teknik penilaian yang akan digunakan. ${ }^{10}$ Berdasarkan teori tersebut guru dalam kegiatan pendahuluan ha-

${ }^{9}$ Abdul Majid, Pembelajaran Tematik Terpadu, (Bandung: Remaja Rosdakarya, 2014), 129

10 Peraturan Menteri Pendidikan dan Kebudayaan Republik Indonesia Nomor 103 Tahun 2014 tentang Pedoman Pelaksanaan Pembelajaran 
rus melakukan beberapa langkah-langkah mengkondisikan peserta didik agar siap mengikuti dan menerima pembelajaran di kelas.

Setelah temuan-temuan tersebut didiskusikan dengan teori yang di kembangkan oleh Abdul Majid dan Permendikbud No. 103 tahun 2014, dapat dipahami bahwa guru Madrasah Ibtidaiyah KAHASRI Kota Probolinggo telah melakukan kegiatan pendahuluan sesuaidengan teori langkah-langkah kegiatan pendahuluan. Meskipun dalam pelaksanaanya guru hanya memberikan apersepsi dengan mengulas materi yang telah dipelajari sebelumnya, memberikan stimulus/motivasi agar suasana belajar menyenangkan, dan menyampaikan tujuan dan manfaat pembelajaran.

Maka dapat diketahui hasil penelitian kegiatan pendahuluan dalam pembelajaran K13 di Madrasah Ibtidaiyah KAHASRI Kota Probolinggo menguatkan teori dari Abdul Majid dan Permendikbud No. 103 tahun 2014 dengan memberikan apersepsi dengan mengulas materi yang telah dipelajari sebelumnya, memberikan stimulus/motivasi agar suasana belajar menyenangkan, dan menyampaikan tujuan dan manfaat pembelajaran.

b. Kegiatan Inti

Kegiatan inti merupakan kegiatan pokok dalam pelakanaan pembelajaran karena dalam kegiatan ini melakukan pembahasan terhadap materi pembelajaran melalui berbagai kegiatan belajar dengan menggunakan multimetode dan media sehingga peserta didik mendapatkan pengalaman belajar yang bermakna.

Berdasarkan temuan hasil penelitian di Madrasah Ibtidaiyah KAHASRI Kota Probolinggo dalam pelaksanaan kegiatan inti guru telah melakukan kegiatan saintifik yang meliputi kegiatan mengamati, menanya, mencoba, mengasosiasi/mengumpulkan, dan mengkomunikasikan.

Temuan tersebut didialogkan dengan teori yang dikembangkan oleh E.Mulyasa sebagai berikut:

Pembelajaran dengan pendekatan saintifik ini menekankan pada keterlibatan peserta didik dalam berbagai kegiatan yang menekankan pada keterlibatan peserta didik dalam berbagai kegiatan 
yang memungkinkan mereka secara aktif mengamati, menanya, mencoba, menalar, mengkomnikasikan, dan membangun jejaring. ${ }^{11}$

Berdasarkan temuan hasil penelitian di Madrasah Ibtidaiyah KAHASRI Kota Probolinggo menunjukkan bahwa kegiataninti dalam pembelajaran yaitu mengamati, menanya, mencoba, menalar, mengkomunikasikan, dan membangun jejaring.

Berdasarkan hasil observasi dalam pelaksanaan kegiatan inti guru masih mengalami kendala seperti, peserta didik masih belum mampu menerapkan pendekatan saintifik karena perbedaan kondisi dari peserta didik. Namun, guru telah mengatasi dengan mengklasifikasikan peserta didik yang pintar, sedang, dan kurang. Dengan begitu guru bisa mengajar sesuai dengan kondisi dari masing-masing peserta didik.

Temuan tersebut kemudian didialogkan dengan Permedikbud No.103 tahun 2014 sebagai berikut:

Kegiatan inti dalam pembelajaran menggunakan pendekatan saintifik disesuaikan dengan karakteristik mata pelajaran dan peserta didik. Guru memfasilitasi peserta didik untuk melakukan proses mengamati, menanya, mengumpulkan informs/mencoba, menalar/mengasosiasi, dan mengkomunikasikan. ${ }^{12}$

Berdasarkan teori tersebut pelaksanaan pembelajaran dengan pendekatan saintifik harus disesuaikan dengan karakteristik mata pelajaran dan peserta didik sehingga peserta didik mampu mengikuti pembelajaran dengan baik.

Setelah temuan-temuan tesebut didiskusikan dengan teori yang kembangkan oleh E. Mulyasa dan Permendikbud No. 103 tahun 2014, dapat dipahami bahwa pelaksanaan kegiatan inti di Madrasah Ibtidaiyah KAHASRI Kota Probolinggo sudah menerapkan pendekatan saintifik meskipun dalam pelaksanaannya masih mengalami kendala, terutama

${ }^{11}$ E. Mulyasa, Guru dalam Implementasi Kurikulum 2013, (Bandung: Remaja Rosdakarya, 2017), 99

12 Peraturan Menteri Pendidikan dan Kebudayaan Republik Indonesia Nomor 103 Tahun 2014 tentang Pedoman Pelaksanaan Pembelajaran 
perbedaan kondisi peserta didik. Tetapi dapat teratasi dengan mengklasifikasikan kondisi peserta didik.

Maka dapat diketahui dari hasil penelitian kegiatan inti dalam pembelajaran K13 di Madrasah Ibtidaiyah KAHASRI Kota Probolinggo menguatkan teori dari E. Mulyasa dan Permendikbud No. 103 tahun 2014 dengan dilakukannya pendekatan saintifik dalam proses pembelajaran.

c. Kegiatan Penutup

Berdasarkan hasil penelitian dari penelitian di Madrasah Ibtidaiyah KAHASRI Kota Probolinggo kegiatan penutup dilakukan dengan membuat kesimpulan dari materi yang telah dipelajari, merefleksikan materi yang diajarkan, dan memberikan tindak lanjut berupa penugasan.

Temuan tersebut kemudian didialogkan dengan teori yang dikembangkan oleh Fadlilah sebagai berikut:

Kegiatan akhir atau penutup adalah kegiatan yang dimaksudkan untuk mengakhiri proses pembelajaran. Kegiatan ini dpat dimanfaatkan oleh guru untuk menarik kesimpulan tentang materi pembelajarn yang baru saja selesai dilaksanakan. Guru dan peserta didik melakukan refleksi, memberikan tindak lanjut dan evaluasi untuk melihat tingkat keberhasilan pembelajaran. ${ }^{13}$

Berdasarkan teori dapat diketahui bahwa kegiatan penutup meliputi kegiatan menarik kesimpulan, refleksi, memberikan tindak lanjut dan evaluasi.

Temuan tersebut kemudian didialogkan dengan Permendikbud No. 103 tahun 2014 sebagai berikut:

1) Kegiatan guru bersama peserta didik yaitu: (a) membuat rangkuman/simpulan pelajaran; (b) melakukan refleksi terhadap kegiatan yang sudah dilaksanakan; dan (c) memberikan umpan balik terhadap proses dan hasil pembelajaran; dan

2) Kegiatan guru yaitu: (a) melakukan penilaian; (b) merencanakan kegiatan tindak lanjut dalam bentuk pembelajaran remedi, program pengayaan, layanan konseling dan/atau memberikan tugas baik tu-

${ }^{13}$ Fadlilah, Implementasi Kurikulum 2013, 186 
gas individual maupun kelompok sesuai dengan hasil belajar peserta didik; dan (c) menyampaikan rencana pembelajaran pada pertemuan berikutnya. ${ }^{14}$

Berdasarkan Permendikbud No. 103 tahun 2014 dapat diketahui bahwa kegiatan guru dalam penutup adalah melakukan refleksi, menyimpulkan pembelajarann, melakukan penilaian, serta membuat rencana tindak lanjut pembelajaran.

Maka dapat diketahui hasil penelitian dari kegiatan penutup dalam pembelajaran K13 di Madrasah Ibtidaiyah KAHASRI Kota Probolinggo menguatkan teori yang dikembangkan Fadlilah dan Permendikbud No. 103 tahun 2014 dengan melakukan kegiatan penutup berupa menarik kesimpulan, melakukan refleksi pembelajaran, dan memberikan tindak lanjut.

Berdasarkan analisis dari hasil temuan dalam pelaksanaan pembelajaran K13 berupa kegiatan pendahuluan, kegiatan inti, dan kegiatan penutup. Dapat ditarik kesimpulan bahwa hasil temuan tersebut menguatkan teori yang dikembangkan oleh Permendikbud No. 103 tahun 2014 dengan melakukan kegiatan pembelajaran dengan langkah-langkah meliputi: kegiatan pendahuluan, inti, dan penutup.

\section{Evaluasi Pembelajaran Kurikulum 2013 di Madrasah Ibtidaiyah KA- HASRI Kota Probolinggo Tahun Pelajaran 2018/2019}

Dari data yang diperoleh di lapangan evaluasi yang dilakukan oleh guru di Madrasah Ibtidaiyah KAHASRI Kota Probolinggo dengan menggunakan penilaian autentik. Dalam setiap pembelajaran guru harus melakukan tiga penilaian. Dari aspek sikap sosial pengetahuan, dan keterampilan. Untuk aspek sikap sosial dinilai dari KI 1 dan KI 2, meliputi: akhlak, sopan santun, kerjasama, disiplin. Aspek pengetahuan dinilai dari penugasan yang terkait KI 3 melalui penugasan ataupun tes tulis. Aspek keterampilan dinilai dari penugasan yang terkait KI 4.

Temuan tersebut kemudian didialogkan dengan Permendikbud No. 23 Tahun 2016 Tentang Standar Penilaian Pendidikan sebagai berikut:

${ }^{14}$ Peraturan Menteri Pendidikan dan Kebudayaan Republik Indonesia Nomor 103 Tahun 2014 tentang Pedoman Pelaksanaan Pembelajaran 
Aspek penilaian autentik pada pembelajaran dengan menggunakan kurikulum 2013 yaitu: aspek sikap, aspek pengetahuan, dan aspek keterampilan. ${ }^{15}$

Berdasarkan teori dapat diketahui bahwa penilaian autentik meliputi 3 aspek yaitu: aspek sikap, aspek pengetahuan, dan aspek keterampilan.

Maka dapat diketahui hasil penelitian dari evaluasi pembelajaran $\mathrm{KI} 3$ di Madrasah Ibtidaiyah KAHASRI Kota Probolinggo menguatkan teori yang dikembangkan Permendikbud No. 23 Tahun 2016 dengan melakukan penilaian autentik meliputi: aspek sikap, aspek pengetahuan, dan aspek keterampilan.

\section{KESIMPULAN}

Berdasarkan hasil peneltian yang telah dilakukan, implementasi kurikulum 2013 di Madrasah Ibtidaiyah KAHASRI Kota Probolinggo Tahun Pelajaran 2018/2019, maka hasil penelitian disampaikan sebagai berikut:

1. Perencanaan Pebelajaran di Madrasah Ibtidaiyah KAHASRI Kota Probolinggo Tahun Pelajaran 2018/2019 adalah dengan membuat perangkat pembelajaran berupa Kalender Pendidikan, RPE, Prota, Promes, Silabus, dan RPP. Dalam pembuatan perangkat pembelajaran ada guru yang membuat perangkat pembelajaran secara individu dan ada yang dengan bersama KKG (Kelompok Kerja Guru).

2. Pelaksanaan Pembelajaran di Madrasah Ibtidaiyah KAHASRI Kota Probolinggo Tahun Pelajaran 2018/2019 meliputi 3 kegiatan yaitu, kegiatan pendahuluan, inti, dan penutup. Kegiatan pendahuluan diawali dengan memberikan apersepsi, memberikan stimulus/motivasi, dan menyampaikan tujuan dan manfaat pembelajaran. Kegiatan pendahuluan diselingi dengan membaca doa sehari-hari dan surat-surat pendek. Kemudian peserta didik diajak menyanyikan lagu nasional untuk meningkatkan rasa nasionalisme. Kegiatan inti guru dilakukan dengan pendekatan saintifik yang meliputi kegiatan mengamati, menanya, mencoba, mengasosiasi/mengumpulkan, dan mengkomunikasikan. Kegiatan penutup dilakukan dengan membuat kesimpulan dari materi yang telah dipelajari, merefleksikan materi yang diajarkan, dan memberikan tindak

15 Peraturan Menteri Pendidikan dan Kebudayaan Republik Indonesia Nomor 23 Tahun 2016 Tentang Standar Penilaian Pendidikan 
lanjut berupa penugasan.

3. Evaluasi Pembelajaran di Madrasah Ibtidaiyah KAHASRI Kota Probolinggo Tahun Pelajaran 2018/2019 menggunakan penilaian autentik yang meliputi 3 aspek yaitu: aspek sikap, aspek pengetahuan, dan aspek keterampilan. Untuk aspek sikap sosial dinilai dari KI l dan KI 2, meliputi: akhlak, sopan santun, kerjasama, disiplin. Aspek pengetahuan dinilai dari penugasan yang terkait KI 3 melalui penugasan ataupun tes tulis. Aspek keterampilan dinilai dari penugasan yang terkait KI 4.

\section{DAFTAR PUSTAKA}

Fadlilah. 2013, Implementasi Kurikulum 2013 Dalam Pembelajaran MI/SD. Jakarta: Ar Ruzz Media.

Majid, Abdul. 2014. Pembelajaran Tematik Terpadu. Bandung: Remaja

Mulyasa, E. 2017. Guru dalam Implementasi Kurikulum 2013. Bandung: Remaja Rosdakarya.

Nurdin, Syafruddin dan Adriantoni. 2016. Kurikulum dan Pembelajaran. Jakarta: Rajawali Press Rosdajarya

Peraturan Menteri Pendidikan dan Kebudayaan Republik Indonesia No. 65 Tahun 2013 tentang standar proses pendidikan dasar dan menengah.

Peraturan Menteri Pendidikan dan Kebudayaan Republik Indonesia Nomor 68 Tahun 2013 tentang Kurikulum SMP-MTs.

Peraturan Menteri Pendidikan dan Kebudayaan Republik Indonesia Nomor 103 Tahun 2014 tentang Pedoman Pelaksanaan Pembelajaran

Peraturan Menteri Pendidikan dan Kebudayaan Republik Indonesia Nomor 22 Tahun 2016 tentang Standar Proses Pendidikan Dasar dan Menengah

Peraturan Menteri Pendidikan dan Kebudayaan Republik Indonesia Nomor 23 Tahun 2016 Tentang Standar Penilaian Pendidikan

Sanjaya, Wina. 2009. Perencanaan Pembelajaran dan Desain Sistem Pembelajaran. Jakarta: Kencana Prenada Media Group.

Sunarti dan Rahmawati, Selly. 2014. Penilaian dalam Kurikulum 2013: Membantu Guru dan Calon Guru Mengetahui Langkah-Langkah Penilaian Pembelajaran. Yogyakarta: CV Andi Offset. 